\title{
CHEMICAL PROFILE AND ANTIOXIDANT POTENTIAL OF FOUR TABLE GRAPE (Vitis vinifera) CULTIVARS GROWN IN DOURO REGION, PORTUGAL
}

\section{PERFIL QUÍMICO E POTENCIAL ANTIOXIDANTE DE QUATRO CULTIVARES DE UVAS DE MESA (Vitis vinifera) PRODUZIDAS NA REGIÃO DO DOURO, PORTUGAL}

\author{
Ana Mota ${ }^{1,3}$, Joana Pinto ${ }^{1,3}$, Ivo Fartouce ${ }^{1,3}$, Maria José Correia ${ }^{1}$, Rui Costa ${ }^{1}$, Rosa Carvalho ${ }^{1}$, Alfredo \\ Aires $^{1,2^{*}}$, Ana Alexandra Oliveira ${ }^{1,2}$ \\ ${ }^{1}$ Escola das Ciências Agrárias e Veterinárias, Universidade de Trás-os-Montes e Alto Douro, UTAD, Quinta de Prados, 5000-801 Vila Real, \\ Portugal. \\ ${ }^{2}$ Centre for the Research and Technology for Agro-Environment and Biological Sciences, CITAB, Universidade de Trás-os-Montes e Alto Douro, \\ UTAD, Quinta de Prados, 5000-801 Vila Real, Portugal. \\ ${ }^{3}$ Bolseiro de Investigação do projeto INNOVINE\&WINE. \\ * Corresponding author: Tel: +351259350115, e-mail: alfredoa@utad.pt
}

(Received 24.04.2018. Accepted 05.09.2018)

\section{SUMMARY}

The aim of this work was to improve the knowledge about the potential of Douro region (North of Portugal) to produce table grapes of superior quality. Skin, pulp, and seeds of four table grapes 'Alphonse Lavallée', 'Cardinal', 'Dona Maria' and 'Muscat Hamburgo' produced in Dour region, collected at commercial maturity stage, were evaluated. Phenolic compounds, organic acids and sugars were determined in each cultivar and in the different parts of the grape by HPLC-DAD, while the antioxidant properties were evaluated by DPPH, Cuprac and lipid peroxidation assays. Phenolics from different classes were found: four anthocyanins (delphynidin, cyanidin, petunidin and malvidin), two hydroxibenzoic acids (gallic acid and protocatechuic acid), three hydroxycinnamic acids (caffeic, chlorogenic and coumaric acids), one flavonol (rutin), three flavan-3ols ((+)-catechin, (-)-epicatechin, and (-)-epicagallocatechin)), one oligomer (procyanidin B2) and one stilbene (resveratrol). In addition, three organic acids (tartaric, malic and citric acids) and two types of sugars (glucose and fructose) were detected in all samples. Differences were found between cultivars $(\mathrm{p}<0.001)$ and sample material type $(\mathrm{p}<0.001)$. Skins presented the higher content in anthocyanins, seeds in flavan-3-ols and pulps in phenolic acids, organic acids and free-sugars. The cultivar 'Cardinal' showed the highest content in phytochemicals, while 'Dona Maria' was the cultivar with the lowest content. Nonetheless, the content of flavan-3-ols and organic acids in 'Dona Maria', associated with its higher antioxidant capacity, makes it an interesting choice as table grape from healthier point of view. According to our results, Douro region have proper environmental conditions to produce these table grapes.

\section{RESUMO}

Com este trabalho pretendeu-se aprofundar o conhecimento sobre o potencial da região do Douro (norte de Portugal) para a produção de uvas de mesa de qualidade superior. Foram avaliadas diferentes partes dos bagos (película, polpa e grainhas) de uva de mesa de quatro cultivares distintas, 'Alphonse Lavallée', 'Cardinal', 'Dona Maria' e 'Moscatel de Hamburgo' produzidas na região Douro e colhidas em plena fase de maturação comercial. Em cada cultivar e nas diferentes partes dos bagos procedeu-se à avaliação dos teores em composto fenólicos, ácidos orgânicos e açúcares por HPLC-DAD. As propriedades antioxidantes foram avaliadas pelos métodos de DPPH, Cuprac e peroxidação lipídica. Foram encontradas diferenças significativas entre cultivares $(p<0,001)$ e tipo de material analisado $(p<0,001)$. Os principais compostos fenólicos encontrados foram: quatro antocianinas (delfinidina, cianidina, petunidina e malvidina), dois ácidos hidroxibenzóicos (ácidos gálico e protocatecuico), três ácidos hidroxicinâmicos (ácidos cafeico, clorogénico e cumárico), um flavonol (rutina), três flavanóis $((+)$-catequina, $(-)-$ epicatequina e (-)-epicagalhocatequina)), um oligómero (procianidina B2) e um estilbeno (resveratrol). Acrescem ainda, três ácidos orgânicos (ácido tartárico, málico e cítrico) e dois tipos de açúcares (glucose e frutose). De acordo com os resultados, as películas apresentaram teores mais elevados em antocianinas, as grainhas em flavanóis e as polpas em ácidos fenólicos, ácidos orgânicos e açúcares livres. De entre as cultivares avaliadas, destaca-se a cultivar 'Cardinal' por apresentar um maior teor médio em fitoquímicos e a cultivar 'Dona Maria' por apresentar um elevado teor em ácidos orgânicos e flavanóis o que, associada à sua elevada capacidade antioxidante, a torna uma cultivar interessante como uma uva de mesa bastante saudável. Baseado nos resultados obtidos, podemos afirmar a região do Douro tem condições ambientais adequadas para a produção destas uvas de mesa.

Key words: table grapes, Douro region, chemical composition, bioactive compounds, quality. Palavras-chave: uvas de mesa, Douro, composição química, compostos bioativos, qualidade.

\section{5}

This is an Open Access article distributed under the terms of the Creative Commons Attribution License (http://creativecommons.org/licenses/by/4.0), which permits unrestricted use, distribution, and reproduction in any medium, provided the original work is properly cited. 


\section{INTRODUCTION}

Grapes are one of the most popular and widely cultivated groups of berry fruits in the world. There are about more than 50 species of grapes (Remaily, 1987) and most of them are found in temperate zones, between latitudes of $40^{\circ}$ and $50^{\circ} \mathrm{N}$ in northern hemisphere and between latitudes of $30^{\circ}$ and $40^{\circ} \mathrm{S}$ in the southern hemisphere (Kok, 2014). However, in recent times, the production of grapes extended to tropical and subtropical countries such as Bolivia, Brazil, Colombia, Peru, Guatemala (in South America), Madagascar, Namibia, Tanzania (in Africa) and Vietnam, China and India (in Asia) (Jogaiah et al., 2013). In Portugal, the viticulture activities are one of the most relevant socio-economic activities, with an average of 195 thousands of hectares of planted area in 2016 (OIV, 2017) mainly destined for wine production. Portugal is currently the $11^{\text {th }}$ wine producer with 6.600 million of hectoliters (Aurand, 2017), and the $9^{\text {th }}$ exporter in the world with a total amount of 727 million of Euros in 2016 (OIV, 2017). Portugal is at the top level of the European wine hierarchy, with 31 DOCs (Denominação de Origem Controlada - meaning Controlled Denomination of Origin). Each of these regions has its own strictly defined geographical boundaries. In the north, the Douro and Porto region, former "Douro Demarcated Region", is famous for "Port wine" production and it was responsible for $21 \%$ of total Portuguese wine production in 2016 (IVV, 2017a). In the Douro region as well in other regions of Portugal a large number of grape biotypes and cultivars are present, representing an important source of biodiversity (IVV, 2017b). Nonetheless, the large majority of vineyards are destined for wine production and only few to production of table grapes. Moreover, a consistent information about chemical profile of table grapes produced in the Douro region and the potential of this region to produce table grapes with superior quality is very limited or even null.

Different studies have shown that grapes contain large amounts of antioxidant phytochemicals, including phenolics, flavonoids, anthocyanins, resveratrol and carotenes (Mendes-Pinto et al., 2004; Castillo-Muñoz et al., 2007; Yang et al., 2009; Bunea et al., 2012; Flamini et al., 2013) and other related beneficial compounds for human health. Based on their richness of bioactive compounds, the intake of grapes have been associated with many positive health effects such as cardioprotective, antiinflammatory, anti-carcinogenic, antiviral, and antibacterial (Xia et al., 2010; Ras et al., 2013; Oliveira et al., 2013; Georgiev et al., 2014; Vaisman and Niv, 2015; Rasines-Perea and Teissedre., 2017).
Although the information about chemical properties of wine grapes are widely known, the same information about table grapes is still scarce, particularly with table grapes produced in Portugal and in particularly in the Douro region. International cultivars such as 'Alphonse Lavallée', 'Cardinal', 'Muscat Hamburg, and other table grapes are important for the future of the table grape industry and several studies have shown that they have potential to be grown in different geographies (Mitić et al., 2012; Topalovic et al., 2012; Rolle et al., 2013; Isci et al., 2015; Kok, 2016). However, less information is available about their potential to be produced in Portugal. Similar situation occurs with the cultivar 'Dona Maria'. 'Dona Maria' is a Portuguese cultivar created in 1950 in the research center "Estação Agronómica Nacional", Oeiras, Portugal (Marreiros, 2013) but the physicochemical characterization of their grapes is until now very limited and it is mainly focused on their biometrical properties, such as size, width and length, and chemicals such as soluble solids, acidity and total sugars. No consistent information is available about their content in phenolics, stilbenes, anthocyanins or organic acids. In addition, information about their antioxidant potential is limited. Therefore, we set a study in which we compare the phytochemical profile and antioxidant potential of four different cultivars of table grapes grown in the Douro region ('Alphonse Lavallée', 'Cardinal', 'Dona Maria' and 'Muscat Hamburg'), in order to assess their differences or similarities, and to understand if the Douro region has potential to grown table grapes as it does successfully with wine grapes. Polyphenols, organic acids and sugars were determined at commercial maturity stage using high-performance liquid chromatographic (HPLC) methods, while antioxidant activities were determined by colorimetric methods.

\section{MATERIAL AND METHODS}

\section{Standards and reagents}

All chemicals used in this study were of analytical grade. Citric acid, tartaric acid, malic acid, naringin, glucose and fructose standards were purchased from Sigma-Aldrich (Tauferkichen, Germany). Gallic acid, protocatechuic acid, (+)-catechin, (-)-epicatechin, (-)epigallocatechin, procyanidin B2, resveratrol, chlorogenic acid, coumaric acid, caffeic acid, rutin, cyanidin-3-O-glucoside, delphinidin-3-O-glucoside malvidin-3-O-glucoside, petunidin-3-O-glucoside standards were purchased from Extrasynthèse (Genay, France). Methanol and acetonitrile were HPLC gradient and purchased from Panreac chemistry (Lisbon, Portugal) and Sigma-Aldrich 
(Taufkirchen, Germany), respectively. 2,2,-diphenyl1-picryl-hydrazyl, ammonium acetate (NH4Ac), copper(II)chloride $\left(\mathrm{CuCl}_{2}\right)$, neocuproine, ethanol, benzoyl, pyridine, diethyl ether, iron sulphate (FeSO4), orthophosphoric acid, potassium dihydrogen phosphate, trifluoroacetic acid (TFA), trichloroacetic acid (TCA), tiobarbituric acid (TBA) and trolox were purchased from Sigma-Aldrich (Taufkirchen, Germany). The aqueous solution were prepared using ultra-pure water (Isomanttle UL 5L, Isopad, Gemini BV Laboratory, Apeldoorn Netherlands)

\section{Grape samples}

Four table grapes cultivars, 'Alphonse Lavallée', 'Cardinal', 'Muscat Hamburg' (red grapes) and 'Dona Maria' (white grape) were grown in 1976-17C rootstocks, at the same altitude $(470 \mathrm{~m})$ and in the same type of soils, in Quinta de Prados, Vila Real, Douro region, North of Portugal. $250 \mathrm{~g}$ of grapes from each cultivar and replicate (three replicates per cultivar) were harvested at commercial maturation stage during September 2016. After harvest, the samples were transported to laboratory, where they were divided in skins, pulps and seeds and then freeze-dried (Scanvac Coolsafe 554 Pro, Labogene ${ }^{\mathrm{Tm}}$, Bjarkesvej 5, DK-3450 Allerød Danmark). Each dried part was then milled in a commercial blender (Taurus, Mod. Aromatic, $150 \mathrm{~W}$, Taurus, Spain) until reach a fine powder. The samples were then stored at $-20^{\circ} \mathrm{C}$ until analytical determinations. Moisture contents of grape skins, pulps and seeds were determined to express the results of analytical experiments in fresh weight (FW) basis. The moisture content was calculated by placing the fresh material in a freezedryer under vacuum for 72 hours. The difference between the initial and final weight was used to calculate the moisture content.

\section{Polyphenols}

\section{Extraction}

The extraction of polyphenols from the different parts of the grapes was done using the method adopted by Aires et al. (2017). Briefly, dried powder of each sample $(0.040 \mathrm{~g})$ was extracted in triplicate with 950 $\mu \mathrm{L} 70 \%$ methanol and $50 \mu \mathrm{L}$ of internal standard compound (naringin, Sigma-aldrich, Tauferkichen, Germanay) in a warm-bath at $70^{\circ} \mathrm{C}$ for 30 minutes with intermittent agitation. The extracts were centrifuged at $15286 \mathrm{~g}$ during 15 minutes at $4^{\circ} \mathrm{C}$ (Centrifuge 5804R, Eppendorf, Hamburg, Germany), and the respective supernatants were filtered through PTFE $0.2 \mu \mathrm{m}, 13 \mathrm{~mm}$ (Teknokroma, Spain) to amber HPLC vials (Chromabond 2-SVW(A) ST-CPK, Sigma-Aldrich, Tauferkichen, Germany) to avoid light degradation. The extracts were then stored under refrigeration $\left(-20{ }^{\circ} \mathrm{C}\right)$ prior to the HPLC-DAD analysis.

\section{HPLC-DAD analysis}

The identification and quantification of polyphenols were performed through HPLC-DAD, according to the procedure adopted by Aires et al. (2017). A HPLC (Gilson) system equipped with one mixture chamber (Gilson, model 811A), two pumps (Gilson, model 305 and 306), automatic injector (Gilson, model 231X), oven (Jones chromatography) and a diode array detector (DAD) (Thermo, Finnigan Surveyor detector) was used to identify the polyphenols present in the different parts of the grapes. The mobile phase was composed by water with $0.1 \%$ of TFA (solvent A) and acetonitrile with $0.1 \%$ TFA (solvent B). $10 \mu \mathrm{L}$ of each extract was injected into a C18 column $(250 \mathrm{~mm} \times 4.6 \mathrm{~mm} ; 5 \mu \mathrm{m}$ particle size, ACE, Advanced Chromatography Technologies, Aberdeen, United Kingdom). The elution was performed at a flow rate of $1 \mathrm{~mL} / \mathrm{min}$ with the following gradient: $0 \mathrm{~min} 100 \% \mathrm{~A}, 5 \mathrm{~min}$ $100 \%$ A, $15 \min 80 \%$ A, 30 min 50\% A, 45 min $0 \%$ A, 50 min $0 \%$ A, 55 min $100 \%$ A, and $60 \min 100 \%$ A. The detection was made at 280,320 , and $370 \mathrm{~nm}$ for phenolics in general, and $520 \mathrm{~nm}$ for anthocyanins, in particular. Phytochemicals were identified through peak retention time, UV spectra and UV maxima absorbance bands, along with comparison with those found for commercial external standards. The quantification was performed using the internal standard method and the results (mean \pm standard deviation (SD)) were expressed as $\mu \mathrm{g} / \mathrm{g}$ fresh weight (FW) of three replicates.

\section{Organic acids}

\section{Extraction}

The extraction of organic acids was based on the method performed by Philips et al. (2010). Briefly, one-gram dw was extracted by $10 \mathrm{~mL}$ ultra-pure water in a sonicator (Sonorex Digitec DT 100, Bandelin, Germany) for 5 minutes. Then the extracts were centrifuged at $1960 \mathrm{~g}$ for 15 minutes (Centrico 250, UniEquip Laborgerätebau- und Vertriebs, Germany), filtered through a $0.20 \mu \mathrm{m}$ PTFE, $13 \mathrm{~mm}$ (Teknokroma, Spain) to amber HPLC vials, and kept in $-20{ }^{\circ} \mathrm{C}$ until analytical determination by HPLC.

\section{HPLC-DAD analysis}

The content of organic acids in extracts was determined through HPLC-DAD, according to the method of Philips et al. (2010), using a HPLC (Gilson) system equipped with one mixture chamber (Gilson, model 811A), two pumps (Gilson, model 305 
and 306), automatic injector (Gilson, model 231X), oven (Jones chromatography) and a diode array detector (DAD) (Thermo, Finnigan Surveyor detector), with a C18 column $(250 \mathrm{~mm} \times 4.6 \mathrm{~mm} ; 5$ $\mu \mathrm{m}$ particle size, ACE, Advanced Chromatography Technologies, Aberdeen, United Kingdom), with a mobile phase of potassium dihydrogen phosphate $(6.8$ $\left.\mathrm{g} \mathrm{L}^{-1}\right)$ and $85 \%$ orthophosphoric acid $(\mathrm{pH} \mathrm{2.1)}$, under isocratic conditions, with a flow rate of $0.8 \mathrm{~mL} / \mathrm{min}$ and an injection volume of $20 \mu \mathrm{L}$. The detection was made at $210 \mathrm{~nm}$. The identification of organic acids was made comparing with commercial pure external standards, their peak retention time, UV spectra and UV maxima absorbance bands. The results were expressed as $\mathrm{mg} / \mathrm{g}$ FW.

\section{Individual Sugars}

\section{Extraction}

For extraction of soluble-free sugars the method of Daniel et al. (1981) was followed, in which $100 \mathrm{mg}$ $\mathrm{dw}$ of each sample was homogenized with $80 \%$ aqueous ethanol $(5 \mathrm{~mL})$ at $20{ }^{\circ} \mathrm{C}$ for $2 \mathrm{~h}$, centrifuged at $1960 \mathrm{~g}$ during 10 minutes at $4{ }^{\circ} \mathrm{C}$ (Centrico 250, UniEquip Laborgerätebau- und Vertriebs, Germany). Afterwards, $100 \mu \mathrm{L}$ of each supernatant was completed evaporated under nitrogen atmosphere, followed by addition of $500 \mu \mathrm{L}$ of derivatization reagent $(10 \%$ benzoyl in pyridine). The mixtures were heated at $37^{\circ} \mathrm{C}$ for $16 \mathrm{~h}$ and then $1 \mathrm{~mL}$ of diethyl ether was added, followed by a vigorous agitation in a vortex. The extracts were then centrifuged at $15286 \mathrm{~g}$ (Centrifuge 5804R, Eppendorf, Hamburg, Germany) for 20 minutes at $4{ }^{\circ} \mathrm{C}$. Then, $750 \mu \mathrm{L}$ of each supernatant was transferred to another vial and dried until complete evaporation under nitrogen atmosphere. After that, each residue was diluted with $750 \mu \mathrm{L}$ of $100 \%$ methanol and kept in $-20{ }^{\circ} \mathrm{C}$ until determination of sugars by HPLC.

\section{HPLC-DAD analysis}

Adopting the same procedure of Daniel et al. (1981) but with small modifications, the individual sugars were determined through HPLC-DAD. A HPLC (Gilson) system equipped with one mixture chamber (Gilson, model 811A), two pumps (Gilson, model 305 and 306), automatic injector (Gilson, model 231X), oven (Jones chromatography) and a diode array detector (DAD) (Thermo, Finnigan Surveyor detector) was used. The mobile phase was composed by water with $0.1 \%$ of TFA (solvent A) and acetonitrile with $0.1 \%$ TFA (solvent B). The elution was performed using a flow rate of $1 \mathrm{~mL} / \mathrm{min}$, with the following gradient: $20 \% \mathrm{~A}$ (0-10 minutes), 7\% A (7$10 \mathrm{~min}), 10 \% \mathrm{~A}(10-12 \mathrm{~min}), 0 \% \mathrm{~A}$ (12-20 min), $0 \%$ A (20-25 min), 20\% A (25-30 min), 20\% A (30-35 min). The injection volume was $20 \mu \mathrm{L}$ and the detection was made at $270 \mathrm{~nm}$. The separation and identification of individual sugars was done by comparing with commercial pure external standards, their retention time, UV spectra and UV max absorbance bands. The results were expressed as $\mathrm{mg} / \mathrm{g} \mathrm{FW}$.

\section{Antioxidant activities}

\section{Extraction}

To determine the antioxidant activity of each grape cultivar an additional extraction was done using the same procedure adopted for the polyphenol extraction but without internal standard.

\section{DPPH radical scavenging activity}

The DPPH radical scavenging activity of each extract was determined using the 2,2-diphenyl-1-picrylhydrazyl (DPPH) assay (Siddhraju and Becker, 2003) conducted in a 96-microplate wells. A freshly $100 \mu \mathrm{M}$ DPPH solution (4 mg of 2.2-diphenyl-1picrylhydrazyl radical in $100 \mathrm{~mL}$ of $95 \%$ of aqueous ethanol) was prepared and added to each microplate well (285 $\mu \mathrm{L}$ of DPPH solution ), followed by the addition of $15 \mu \mathrm{L}$ extract. A blank sample (all reagents and extraction solvent instead of sample) was considered in the first well of microplate. After that, the microplates were incubated in the dark, at room temperature for 30 minutes. After this period, the absorbance values were recorded at $517 \mathrm{~nm}$ wavelength in a microplate reader (Multiskan ${ }^{\mathrm{TM}} \mathrm{FC}$ Microplate Photometer, USA), and the results were expressed as \% DPPH radical scavenging capacity, using the following formula: \% DPPH scavenging capacity $=\left(\mathrm{Abs}_{\text {blank }}-\mathrm{Abs}_{\text {sample }} / \mathrm{Abs}_{\text {blank }}\right) \times 100$

Cupric ion reducing antioxidant capacity (CUPRAC)

The CUPRAC assay was performed using the classical method of Apak et al. (2004) with small modifications and conducted in a 96 microplate wells. Briefly, to each well of microplate was added sequentially $50 \mu \mathrm{L}$ of $\mathrm{CuCl}_{2}$ (10 mM in water), $50 \mu \mathrm{L}$ of neocuproine (Sigma-Aldrich, Tauferkichen, Germany) at $7.5 \mathrm{mM}$ in $96 \%$ ethanol, and $50 \mu \mathrm{L}$ of NH4Ac buffer ( $1 \mathrm{mM}$ in water, $\mathrm{pH} 7.0), 25 \mu \mathrm{L}$ of sample and $25 \mu \mathrm{L}$ of double distilled water. The microplates were then incubated in the dark at room temperature for 30 minutes and after the values of absorbance were recorded at $450 \mathrm{~nm}$ against blank (all reagents except $\mathrm{CuCl}_{2}$ ) in a microplate reader (Multiskan $^{\text {TM }}$ FC Microplate Photometer, USA). A calibration curve was made using the commercial compound trolox as standard and the results were expressed as $\mu \mathrm{M}$ of trolox equivalents per $\mathrm{g}$ of fresh sample ( $\mu \mathrm{M}$ TE/g FW). 


\section{Inhibition of lipid peroxidation bioassay}

The inhibition of lipid peroxidation assay was used to measure the lipid peroxide formed using egg yolk homogenates as lipid-rich media, as described by Dakera et al. (2008). Briefly, in a microplate of 96 wells, $20 \mu \mathrm{L}$ of substrate (homogenate of egg yolk at $10 \%$ in $0.1 \mathrm{M}$ phosphate buffer, $\mathrm{pH} 7.4$ ) was added followed $\mathrm{d}$ by addition of $5 \mu \mathrm{L}$ of FeSO4 $(1 \mathrm{mM}$ in water), $20 \mu \mathrm{L}$ of plant extract and $65 \mu \mathrm{L}$ of double distilled water. The microplates were then incubated at $37{ }^{\circ} \mathrm{C}$ for 15 minutes. After this period, $50 \mu \mathrm{L}$ of tricloroacetic acid (50\% in water) and $100 \mu \mathrm{L}$ of tiobarbituric acid (TBA) $(0.8 \%$ in phosphate buffer) were added sequentially to each microplate followed by a new incubation at $95{ }^{\circ} \mathrm{C}$ for 15 minutes until a pink colour appearance. Then, the absorbance values were recorded at $532 \mathrm{~nm}$ in a microplate reader (Multiskan $^{\mathrm{TM}}$ FC Microplate Photometer, USA). A complete oxidized extract (egg yolk $+\mathrm{FeSO}_{4}$, without extract) was used as control. The results were expressed as \% lipid peroxidation inhibition using the following formula: $(\%)$ lipid peroxidation inhibition $=$ $\left(\mathrm{Abs}_{\text {control }}-\mathrm{Abs}_{\text {sample }} / \mathrm{Abs}_{\text {control }}\right) \times 100$.

\section{Statistical analysis}

All data were expressed as mean \pm standard deviation (SD) of triplicate determinations. The mean values were compared using ANOVA, and the Duncan test was used to determine differences between cultivars and between grape parts with statistical significance. Statistical analysis was carried out using SPSS version 17 Software (SPSS-IBM, Orchard RoadArmonk, New York, USA). A principal component analysis (PCA) using JMP version 13.2.1 Software (SAS Institute, Inc., Cary, USA) in order to identify which variables determine similarities and differences between grape cultivars.

\section{RESULTS AND DISCUSSION}

The content of phenolic acids, flavonoids, anthocyanins, stilbenes (resveratrol), organic acids and free sugars are presented in Tables I to III, and their levels varied significantly with cultivar $(p<0.001)$ and with berry fraction evaluated $(\mathrm{p}<0.001)$.

\section{TABLE I}

Average levels of phenolic acids, flavonoids and stilbenes $(\mu \mathrm{g} / \mathrm{g} \mathrm{FW})$ found in the four table grapes by HPLC-DAD at different wavelenght

Teores médios em ácidos fenólicos, flavonóides e estilbenos ( $\mu \mathrm{g} / \mathrm{g}$ peso fresco) nas quatro cultivares de uva de mesa por HPLC-DAD a diferentes comprimentos de onda

\begin{tabular}{|c|c|c|c|c|c|c|c|c|c|c|c|c|}
\hline \multirow{2}{*}{ Cultivar } & \multirow{2}{*}{$\begin{array}{l}\text { Sample } \\
\text { part }\end{array}$} & \multicolumn{2}{|c|}{$250 \mathrm{~nm}$} & \multicolumn{4}{|c|}{$280 \mathrm{~nm}$} & \multirow{2}{*}{$\begin{array}{c}306 \mathrm{~nm} \\
\text { Resv }\end{array}$} & \multicolumn{3}{|c|}{$320 \mathrm{~nm}$} & \multirow{2}{*}{$\frac{370 \mathrm{~nm}}{\text { Rut }}$} \\
\hline & & Gall & Protocat & Cat & Epicat & Procyan & Epigall & & Chlor & Coum & Caf & \\
\hline \multirow{3}{*}{$\begin{array}{l}\text { 'Alponse } \\
\text { Lavallée' }\end{array}$} & Seeds & $7.7 \pm 0.8$ & $12.0 \pm 0.4$ & $20.7 \pm 1.1$ & $36.3 \pm 2.4$ & $21.1 \pm 1.3$ & $26.9 \pm 1.3$ & n.d. & n.d. & n.d. & n.d. & n.d. \\
\hline & Skin & n.d. & n.d. & n.d. & n.d. & n.d. & n.d. & n.d. & n.d. & n.d. & n.d. & $73.3 \pm 8.7$ \\
\hline & Pulp & n.d. & n.d. & n.d. & n.d. & n.d. & n.d. & n.d. & $7.7 \pm 0.3$ & $0.7 \pm 0.2$ & $1.3 \pm 0.7$ & n.d. \\
\hline \multirow{3}{*}{ 'Cardinal' } & Seeds & $29.7 \pm 7.6$ & n.d. & $109.9 \pm 3.1$ & $130.4 \pm 12.2$ & $59.7 \pm 12.4$ & $27.8 \pm 8.6$ & n.d. & n.d. & n.d. & n.d. & n.d. \\
\hline & Skin & n.d. & n.d. & n.d. & n.d. & n.d. & n.d. & $21.5 \pm 4.3$ & n.d. & n.d. & n.d. & $49.9 \pm 5.0$ \\
\hline & Pulp & n.d. & n.d. & n.d. & n.d. & n.d. & n.d. & n.d. & $3.0 \pm 0.3$ & n.d. & n.d. & n.d. \\
\hline \multirow{3}{*}{$\begin{array}{l}\text { 'Dona } \\
\text { Maria' }\end{array}$} & Seeds & n.d. & $5.9 \pm 0.4$ & $16.6 \pm 1.2$ & $27.6 \pm 1.0$ & $9.4 \pm 1.2$ & $12.59 \pm 0.5$ & n.d. & n.d. & n.d. & n.d. & n.d. \\
\hline & Skin & n.d. & n.d. & n.d. & n.d. & n.d. & n.d. & n.d. & $19.0 \pm 1.6$ & $2.2 \pm 0.3$ & n.d. & $26.1 \pm 1.3$ \\
\hline & Pulp & n.d. & n.d. & n.d. & n.d. & n.d. & n.d. & n.d. & n.d. & n.d. & n.d. & n.d. \\
\hline \multirow{3}{*}{$\begin{array}{l}\text { 'Muscat } \\
\text { Hamburg' }\end{array}$} & Seeds & $18.3 \pm 1.2$ & $20.3 \pm 1.0$ & $38.3 \pm 3.4$ & $60.9 \pm 10.0$ & $36.7 \pm 0.4$ & $44.5 \pm 4.7$ & n.d. & n.d. & n.d. & n.d. & n.d. \\
\hline & Skin & n.d. & n.d. & n.d. & n.d. & n.d. & n.d. & n.d. & n.d. & n.d. & n.d. & $129.1 \pm 3.2$ \\
\hline & Pulp & n.d. & n.d. & n.d. & n.d. & n.d. & n.d. & n.d. & $8.5 \pm 0.5$ & n.d. & n.d. & n.d. \\
\hline \multicolumn{13}{|c|}{ Source of variation } \\
\hline \multirow{2}{*}{\multicolumn{2}{|c|}{$\begin{array}{c}\text { Cultivar (C) } \\
\text { Sample part (S) }\end{array}$}} & $* * *$ & $* * *$ & $* * *$ & $* * *$ & $* * *$ & $* * *$ & $* * *$ & $* * *$ & $* * *$ & $* * *$ & $* * *$ \\
\hline & & $* * *$ & $* * *$ & $* * *$ & $* * *$ & $* * *$ & $* * *$ & $* * *$ & $* * *$ & $* * *$ & $* * *$ & $* * *$ \\
\hline \multicolumn{2}{|c|}{$\mathrm{CxS}$} & **** & $* * *$ & $* * *$ & $* * *$ & $* * *$ & $* * *$ & $* * *$ & $* * *$ & $* * *$ & $* * *$ & $* * *$ \\
\hline
\end{tabular}

Gall - Gallic acid; Protocat - Protocatechuic acid; Cat - (+)-Catechin; Epicat - (-)-Epicatechin; Procyan - Procyanidin B2; Epigall - (-)-Epigallocatechin; Resv -

Resveratrol; Chlor - Chlorogenic acid; Coum - Coumaric acid; Caf - Caffeic acid; Rut - Rutin. Values are expressed as mean \pm standard deviation of three replicates.

The symbols means: not detected (n.d.); highly significant $(* * *$, at $\mathrm{p}<0.001)$

The 'Cardinal' presented the highest mean of total polyphenols (sum of individual phenolics from the different berry parts) $(850.4 \mu \mathrm{g} / \mathrm{g} \mathrm{FW})$ followed by 'Muscat Hamburg' (753.1 $\mu \mathrm{g} / \mathrm{g}$ FW), 'Alphonse Lavallée' (582.1 $\mu \mathrm{g} / \mathrm{g} \mathrm{FW})$ and 'Dona Maria' (125.2 $\mu \mathrm{g} / \mathrm{g} F W$ ). As expected, red grapes showed highest content of polyphenols (Tables I and II) and the fractions of seeds and skins have significantly higher concentration of polyphenols than those determined for pulps. 
TABLE II

Average levels of anthocyanins $(\mu \mathrm{g} / \mathrm{g} \mathrm{FW})$ found in the four table grapes by HPLC-DAD at $520 \mathrm{~nm}$ wavelenght ${ }^{3}$

Teores médios de antocianinas ( $\mu \mathrm{g} / \mathrm{g}$ peso fresco) nas quatro cultivares de uva de mesa determinadas por HPLC-DAD a u comprimento de onda de $520 \mathrm{~nm}$

\begin{tabular}{|c|c|c|c|c|c|}
\hline Cultivar & $\begin{array}{l}\text { Sample } \\
\text { part }\end{array}$ & $\begin{array}{l}\text { Delfinidin-3-O- } \\
\text { glucoside }\end{array}$ & $\begin{array}{l}\text { Cyanidin-3-O- } \\
\text { glucoside }\end{array}$ & $\begin{array}{l}\text { Petunidin-3-O- } \\
\text { glucoside }\end{array}$ & $\begin{array}{l}\text { Malvidin-3-O- } \\
\text { glucoside }\end{array}$ \\
\hline \multirow{3}{*}{$\begin{array}{l}\text { 'Alponse } \\
\text { Lavallée’ }\end{array}$} & Seeds & n.d. & $0.07 \pm 0.0 \mathrm{a}$ & n.d. & $1.0 \pm 0.0 \mathrm{a}$ \\
\hline & Skin & n.d. & $22.70 \pm 1.5 \mathrm{c}$ & n.d. & $348.7 \pm 6.9 \mathrm{~b}$ \\
\hline & Pulp & $0.15 \pm 0.0$ & $1.60 \pm 0.1 \mathrm{~b}$ & n.d. & n.d. \\
\hline \multirow{3}{*}{ 'Cardinal' } & Seeds & n.d. & $0.21 \pm 0.0 \mathrm{a}$ & n.d. & $3.0 \pm 0.2 \mathrm{a}$ \\
\hline & Skin & $21.90 \pm 2.0 \mathrm{~b}$ & $48.10 \pm 1.7 \mathrm{c}$ & $82.1 \pm 1.3$ & $256.7 \pm 6.0 \mathrm{~b}$ \\
\hline & Pulp & $0.70 \pm 0.0 \mathrm{a}$ & $2.20 \pm 0.3 b$ & n.d. & n.d. \\
\hline \multirow{3}{*}{$\begin{array}{l}\text { 'Dona } \\
\text { Maria' }\end{array}$} & Seeds & n.d. & $0.09 \pm 0.0 \mathrm{a}$ & n.d. & $0.94 \pm 0.0 \mathrm{a}$ \\
\hline & Skin & n.d. & $0.27 \pm 0.0 \mathrm{~b}$ & n.d. & $4.37 \pm 0.2 \mathrm{~b}$ \\
\hline & Pulp & n.d. & n.d. & n.d. & n.d. \\
\hline \multirow{3}{*}{$\begin{array}{l}\text { 'Muscat } \\
\text { Hamburg' }\end{array}$} & Seeds & n.d. & $0.23 \pm 0.0 \mathrm{a}$ & n.d. & $2.9 \pm 0.39 \mathrm{a}$ \\
\hline & Skin & n.d. & $38.1 \pm 1.8 \mathrm{c}$ & n.d. & $360.5 \pm 5.6 \mathrm{~b}$ \\
\hline & Pulp & $0.74 \pm 0.1$ & $0.67 \pm 0.0 \mathrm{~b}$ & n.d. & n.d. \\
\hline \multicolumn{6}{|c|}{ Source of variation } \\
\hline \multicolumn{2}{|c|}{ Cultivar (C) } & $* * *$ & $* * *$ & $* * *$ & $* * *$ \\
\hline \multicolumn{2}{|c|}{ Sample part (S) } & $* * *$ & $* * *$ & $* * *$ & $* * *$ \\
\hline \multicolumn{2}{|c|}{$\mathrm{C} \times \mathrm{S}$} & $* * *$ & $* * *$ & $* * *$ & $* * *$ \\
\hline
\end{tabular}

The group of anthocyanins prevails in the skins of different cultivars, while the group of catechins was dominant in the seeds. Instead, the profile of phenolic acid distribution was highly dependent of cultivar. Gallic acid, a hydroxybenzoic acid, prevails in seeds of all cultivars, but chlorogenic acid and coumaric acid, two phenolic acids from hydroxycinnamic acid group, were found in the pulps of 'Alphonse Lavallée', 'Cardinal' and Muscat Hamburg', while in 'Dona Maria' grapes they were found in skins. The flavonol rutin, was found in the skins of all studied cultivars. All cultivars presented the same profile of anthocyanins in seeds, when detected, namely malvidin-3-O-glucoside $>$ petunidin-3-O-glucoside $>$ cyanidin-3-O-glucoside $>$ delfinidin-3-O-glucoside (Table II). In all cultivars the highest content of phenolics were found in skins followed by seeds and pulps, which is accordance with Rockenbach et al. (2011) that reported higher content of phenolics in skins of grapes comparatively to seeds and pulps. Also Yilmaz et al. (2015) reported a higher content of phenolics in skins of 22 grapes cultivars (red and white), which is consistently according to our results. Although several authors have reported that pulps of grapes usually do not have any type of anthocyanins, we detected the presence of dephinidin-3-O-glucoside and cyanidin-3-O-glucoside in the pulps of 'Alphonse Lavallée', 'Cardinal' and Muscat Hamburg', which is consistent with the findings of He et al. (2010, 2017), who found the same types anthocyanins in similar cultivars of red grapes.

Literature consistently reports that red grapes are beneficial for human health because they have high amounts of polyphenols and they act as protective agents against inflammatory, mutagenic and degenerative processes (Kumar and Pandey, 2013; Sosa et al., 2013; Hussain et al., 2016). Our findings show that white grapes from 'Dona Maria' could have similar benefits due to their content in catechins, chlorogenic acid and caffeic acid, and rutin. Catechins and respective derivatives have been considered effective scavengers of reactive oxygen species in vitro and may act indirectly as antioxidants through their effects on transcription factors and enzyme activities (Higdon and Frei, 2003). Chlorogenic and caffeic acids, two of the most representative hydroxycinnamic acids have also been associated with the reduction of oxidative and inflammatory stress conditions (Liang and Kitts, 2016). Rutin, a typical flavonol largely abundant in plants and known as quercetin-3-rutinoside, rutoside or vitamin $\mathrm{P}$, has been explored for a number of biological effects such antioxidant, cytoprotective, vasoprotective, anticarcinogenic, neuroprotective and cardioprotective activities (Ganeshpurkar and Saluja, 2017). Therefore, foods (in this case, grapes) with high content of such compounds are thus highly 
beneficial for human health and must be included in the human diet on a daily basis, if possible.

Another important finding of our work is the amount of each polyphenol detected. The average contents for the different parts of the grapes were higher than the values found by other authors for wine and table grapes (Cantos et al., 2002; Topalovic and MikulicPetkovsek, 2010; Ferrandino et al., 2012; Topalovic et al., 2012; Nile et al., 2015), meaning that the Douro region has suitable conditions to produce these table grapes. The significant differences between the values presented in this study and the values from those authors are a consequence of the influence of geographical location, cultural practices, in addition to the varietal differences.

The Table III shown the average content of organic acids, ranging from 0.9 to $43.6 \mathrm{mg} / \mathrm{g} \mathrm{FW}$, and significant differences $(0.001<\mathrm{p}<0.05)$ were found between cultivars. Tartaric acid was predominant in all cultivars and its average levels varied between $31.10 \mathrm{mg} / \mathrm{g} \mathrm{FW}$ in 'Alphonse Lavallée' and 37.38 $\mathrm{mg} / \mathrm{g} \mathrm{FW}$ in 'Dona Maria. Average levels of malic acid were found to be significantly higher in 'Cardinal' (8.3 mg/g FW) whilst citric acid was higher in 'Moscatel Hamburg' ( $4.1 \mathrm{mg} / \mathrm{g}$ FW).

TABLE III

Average content of organic acids and sugars in the four table grapes studied

Teor médio em ácidos orgânicos e açúcares nas quatro cultivares de uva de mesa estudadas

\begin{tabular}{|c|c|c|c|c|c|c|}
\hline \multirow{2}{*}{ Cultivar } & \multirow{2}{*}{$\begin{array}{c}\text { Sample } \\
\text { part }\end{array}$} & \multicolumn{3}{|c|}{ Organic acids (mg/g FW) } & \multicolumn{2}{|c|}{ Sugars ( mg/g FW) } \\
\hline & & Tartaric acid & Malic acid & Citric acid & Glucose & Fructose \\
\hline \multirow{3}{*}{$\begin{array}{l}\text { 'Alponse } \\
\text { Lavallée' }\end{array}$} & Seeds & $1.7 \pm 0.2 \mathrm{a}$ & $1.8 \pm 0.1 \mathrm{a}$ & $1.4 \pm 0.3 \mathrm{a}$ & $7.9 \pm 0.7 \mathrm{a}$ & $8.1 \pm 0.0 \mathrm{a}$ \\
\hline & Skin & $33.3 \pm 1.0 \mathrm{~b}$ & $5.2 \pm 0.8 \mathrm{~b}$ & $1.7 \pm 0.2 \mathrm{a}$ & $167.6 \pm 7.8 \mathrm{~b}$ & $165.5 \pm 5.4 \mathrm{~b}$ \\
\hline & Pulp & $33.7 \pm 0.7 \mathrm{~b}$ & $7.1 \pm 0.8 \mathrm{c}$ & $2.3 \pm 0.3 \mathrm{~b}$ & $210.9 \pm 4.7 \mathrm{c}$ & $299.4 \pm 9.6 \mathrm{c}$ \\
\hline \multirow{3}{*}{ 'Cardinal' } & Seeds & $4.0 \pm 0.3 \mathrm{a}$ & $4.9 \pm 0.6 \mathrm{a}$ & $4.0 \pm 0.2 \mathrm{~b}$ & $99.8 \pm 4.3 \mathrm{a}$ & $94.0 \pm 4.0 \mathrm{a}$ \\
\hline & Skin & $33.9 \pm 1.0 \mathrm{~b}$ & $6.4 \pm 0.8 \mathrm{~b}$ & $2.6 \pm 0.4 \mathrm{a}$ & $123.2 \pm 19.6 \mathrm{~b}$ & $116.5 \pm 4.3 \mathrm{~b}$ \\
\hline & Pulp & $35.9 \pm 2.1 \mathrm{~b}$ & $6.2 \pm 0.5 \mathrm{~b}$ & n.d. & $269.7 \pm 10.8 \mathrm{c}$ & $342.7 \pm 5.9 \mathrm{c}$ \\
\hline \multirow{3}{*}{$\begin{array}{l}\text { 'Dona } \\
\text { Maria' }\end{array}$} & Seeds & $6.7 \pm 0.2 \mathrm{a}$ & $0.6 \pm 0.0 \mathrm{a}$ & n.d. & $18.1 \pm 1.2 \mathrm{a}$ & $18.5 \pm 1.8 \mathrm{a}$ \\
\hline & Skin & $28.0 \pm 1.6 \mathrm{~b}$ & $6.1 \pm 0.7 \mathrm{~b}$ & $0.9 \pm 0.2$ & $141.6 \pm 4.2 \mathrm{~b}$ & $138.5 \pm 2.1 \mathrm{~b}$ \\
\hline & Pulp & $43.6 \pm 2.6$ & $8.8 \pm 0.7 \mathrm{c}$ & n.d. & $238.7 \pm 24.3 \mathrm{c}$ & $313.4 \pm 8.0 \mathrm{c}$ \\
\hline \multirow{3}{*}{$\begin{array}{l}\text { 'Muscat } \\
\text { Hamburg' }\end{array}$} & Seeds & $2.3 \pm 0.5 \mathrm{a}$ & $2.4 \pm 0.2 \mathrm{a}$ & $1.6 \pm 0.2 \mathrm{~b}$ & $9.7 \pm 1.0 \mathrm{a}$ & $11.9 \pm 0.3 \mathrm{a}$ \\
\hline & Skin & $26.4 \pm 0.4 \mathrm{~b}$ & $5.6 \pm 0.2 \mathrm{~b}$ & $2.0 \pm 0.2 \mathrm{~b}$ & $141.6 \pm 21.7 \mathrm{~b}$ & $149.7 \pm 5.0 \mathrm{~b}$ \\
\hline & Pulp & $39.9 \pm 1.7 \mathrm{c}$ & $7.0 \pm 0.4 \mathrm{c}$ & $4.2 \pm 0.3 \mathrm{c}$ & $229.9 \pm 20.6 \mathrm{c}$ & $293.2 \pm 14.4 \mathrm{c}$ \\
\hline \multicolumn{7}{|c|}{ Source of variation } \\
\hline \multicolumn{2}{|c|}{ Cultivar (C) } & $* * *$ & $*$ & $* * *$ & $* * *$ & $* *$ \\
\hline \multicolumn{2}{|c|}{ Sample part (S) } & $* * *$ & $* * *$ & n.s. & $* * *$ & $* * *$ \\
\hline \multicolumn{2}{|c|}{$\mathrm{C} \times \mathrm{S}$} & $* * *$ & $* * *$ & $* * *$ & $* * *$ & $* * *$ \\
\hline
\end{tabular}

As also shown in Table III, the two main sugars identified were fructose (ranging from 35.0 to 360.4 $\mathrm{mg} / \mathrm{g} \mathrm{FW}$ ) followed by glucose (ranging from 28.7 to $295.2 \mathrm{mg} / \mathrm{g} \mathrm{FW}$ ). The highest levels of fructose and glucose were mainly found in berries pulps, followed by skins and seeds.

The levels for organic acids and free sugars in this study for 'Alphonse Lavallée', 'Cardinal' and 'Muscat Hamburg' are in agreement with those reported for tables grapes (Topalovic and MikulicPetkovsek, 2010; Aubert and Chalot, 2018). For 'Dona Maria' grapes, we believe that this is the first time that values for organic acids are reported. The higher contents of tartaric and malic acids and the very low content of citric acid associated with considerable amounts of fructose in pulp and skins, seems to justify why these grapes in Portugal are often reported as one of the most sweetness white table grapes.

The Figure 1 illustrates the average values of antioxidant properties assayed with the DPPH, Cuprac and lipid peroxidation methods. As shown, the antioxidant properties assayed were significantly affected by cultivar and berry part assayed. The highest values were achieved for seeds, followed by skins and pulps, following the same trend observed for the phenolics content. Similar observation was made by Yilmaz et al (2015), which reported high antioxidant activity values in skins and seeds of table grapes extracts and linking them with the high content 
of phenolics in these berry fractions, particularly with anthocyanins. In the current work, the results were consistent in the three methods assayed (Figure 1), which confirms that in the grape cultivars studied the seeds are the part of berry grapes with high antioxidant potential. This trend could be related with its high content of polyphenols, particularly the group of phenolic acids or catechins and procyanidins that are prominent in this part of berries (Table I). Like in phenolics, the highest antioxidant activities were found for 'Cardinal' cultivar in all the three methods assayed, which can be associated with high content of polyphenols in this cultivar (Tables I and II). However, surprisingly, seeds of 'Dona Maria' showed similar antioxidant levels to other three cultivars, probably due to the presence of protocatechuic acid, catechins and anthocyanins (Tables I and II). It means that from the health point of view, 'Dona Maria' grapes have potential due to the richness of antioxidant compounds in its seeds.

According to many authors, antioxidant activity of fruits, vegetables and foods in general, results mainly from the presence of phenolics. The Figure 2 shown the PCA analysis results and it was possible to understand that the group of catechins is critical for the antioxidant activities exhibited by all cultivars studied, particularly by the seeds. The cumulative variation (component $1+$ component 2 ) found in all cultivars (Figure 2) means that variation of antioxidant activity found in 'Cardinal', 'Muscat Hamburg', 'Alphonse Lavallée' and 'Dona Maria' was positively associated with the variation of this group of polyphenols in $99.4,96.5,97.5$ and $99.1 \%$, respectively. According to the PCA analysis, higher values of antioxidant activity exhibited by seeds of 'Cardinal' cultivar were highly related with the contents of (+)-catechin, (-)-epicatechin and procyanidin B2, while in 'Muscat Hamburg' and 'Alphonse Lavallée' the antioxidant activity properties were more dependent on the variations in ()-epicatechin and (-)-epigallocatechin. In 'Dona Maria', the antioxidant activity of its seeds was highly related with the content of (+)-catechin and (-)epicatechin. In the case of skins, the antioxidant activity was more related with the variation of flavanol and phenolic acids, particularly rutin and chlorogenic acid, respectively (Table I, Figures 1 and 2 ). In the case of pulps, only the presence of some anthocyanins, particularly in Cardinal', 'Muscat Hamburg' and 'Alphonse Lavallée' cultivars seems to justify the moderate values of antioxidant activity found for these cultivars (Table II, Figures 1 and 2).In 'Dona Maria' grapes, the absence of any type of polyphenols seems to justify the zero values found for the antioxidant activity.
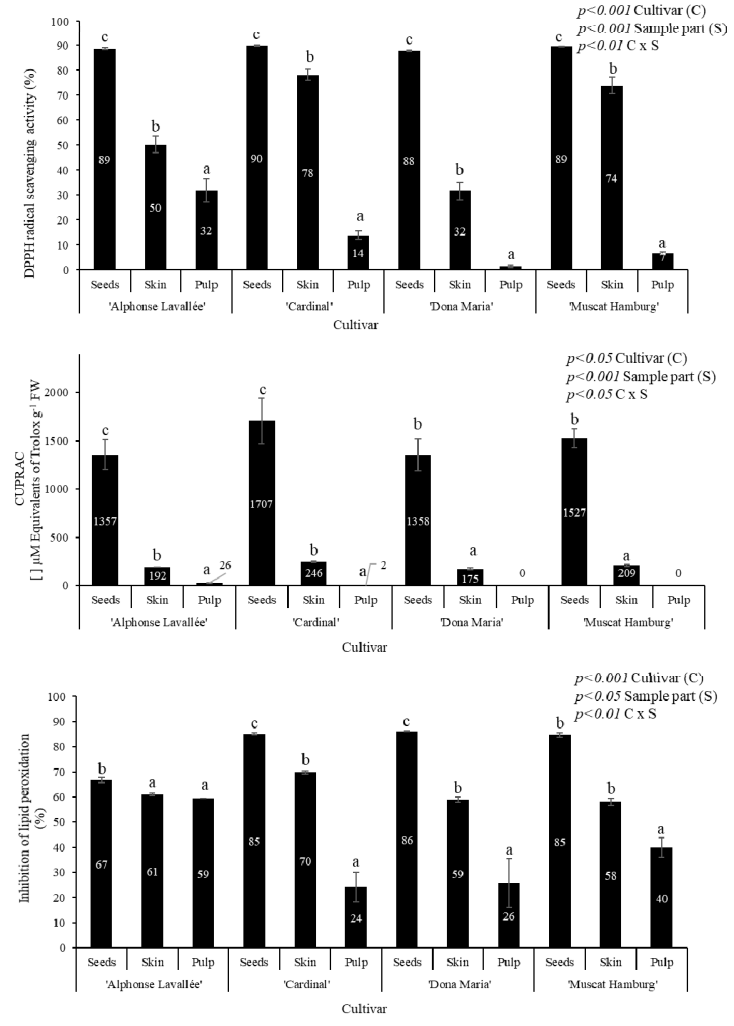

Figure 1. Antioxidant activity of the table grapes studied in the current work. Mean values with different letters for in the same cultivar are significantly different from another at $\mathrm{p}<0.05$ by Duncan test.

Atividade antioxidante nas quatro cultivares de uva de mesa estudadas no presente trabalho. Valores médios com diferentes letras na mesma cultivar são estatisticamente diferentes a $p<0,05$ pelo teste de Duncan.

In addition, the Pearson's correlation coefficients presented in Table IV summarize the most significant positive correlation coefficients between the various parameters evaluated in this study. The highest significant correlations, as we expected after PCA analysis, were found between the group of catechins and antioxidant activities, which seems to justify why the seeds had the highest antioxidant activities (Figure 1). These data clearly show that the antioxidant capacity is dependent on both the level and type of phenolic compounds present. Anthocyanins like delfinidin and cyanidin, and other phenolics such as chlorogenic acid, caffeic acid, rutin and resveratrol are present in lower amounts and thus having lower significance for the antioxidant activity values. Nonetheless, their presence in the studied grapes must not be neglected because increase their quality value, since these compounds have been 

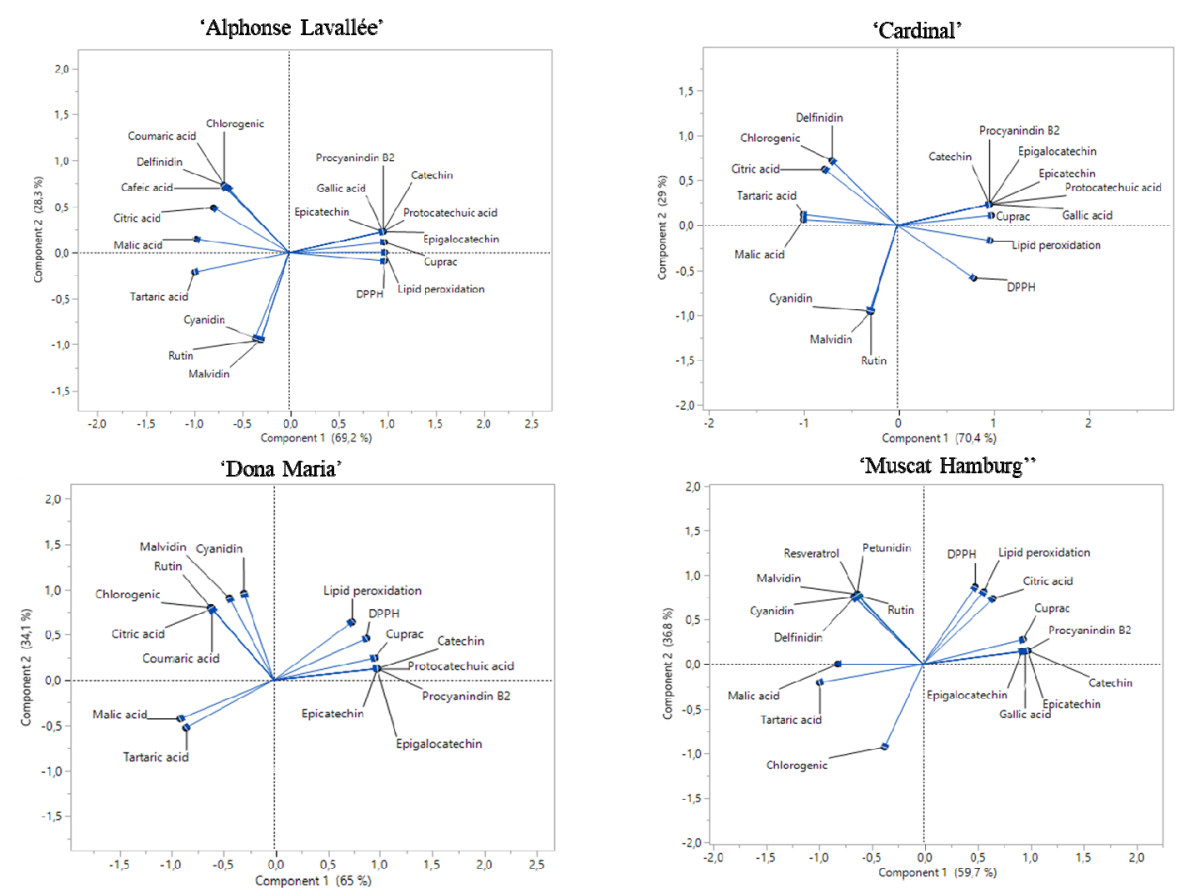

Figure 2. Principal component analysis results.

Resultados da análise em componentes principais.

\section{Table IV}

Correlation coefficients of Pearson's between all polyphenols and organic acids and antioxidant capacity in the four table grapes

Coeficientes de correlação de Pearson entre os teores em polifenóis, ácidos orgânicos e capacidade antioxidante nas quatro cultivares de uva de mesa

\begin{tabular}{|c|c|c|c|c|c|c|c|c|c|c|c|c|c|c|c|c|c|c|c|c|c|c|}
\hline & & 1 & 2 & 3 & 4 & 5 & 6 & 7 & 8 & 9 & 10 & 11 & 12 & 13 & 14 & 15 & 16 & 17 & 18 & 19 & 20 & 21 \\
\hline 1 & Gallic acid & 1 & $0.41^{*}$ & $0.94 * *$ & $0.97 * *$ & $0.95 * *$ & $0.77 * *$ & n.s. & n.s. & n.s. & n.s. & n.s. & n.s. & n.s. & n.s. & n.s. & $-0.69 * *$ & $-0.33^{*}$ & $0.41^{*}$ & $0.53 * *$ & $0.75 * *$ & $0.54 * *$ \\
\hline 2 & Protocatechuic acid & & 1 & n.s. & $0.47 * *$ & n.s. & $0.85^{* *}$ & n.s. & n.s. & n.s. & n.s. & n.s. & n.s. & n.s. & n.s. & n.s. & $-0.72 * *$ & $-0.70^{* *}$ & n.s. & $0.54^{* *}$ & $0.67 * *$ & $0.48^{* *}$ \\
\hline 3 & $(+)$-Catechin & & & 1 & $0.97 * *$ & $0.99 * *$ & $0.69^{*}$ & n.s. & n.s. & n.s. & n.s. & n.s. & n.s. & n.s. & n.s. & n.s. & $-0.68 * *$ & n.s. & $0.42^{*}$ & $0.53 * *$ & $0.78^{* *}$ & $0.57^{* *}$ \\
\hline 4 & Procyanidin B2 & & & & 1 & $0.98 * *$ & $0.84^{* *}$ & n.s. & n.s. & n.s. & n.s. & n.s. & n.s. & n.s. & n.s. & n.s. & $-0.78 * *$ & $-0.45^{*}$ & $0.36^{*}$ & $0.61^{* *}$ & $0.86^{* *}$ & $0.61^{* *}$ \\
\hline 5 & (-)-Epicatechin & & & & & 1 & $0.74 * *$ & n.s. & n.s. & n.s. & n.s. & n.s. & n.s. & n.s. & n.s. & n.s. & $-0.74 * *$ & $-0.41^{*}$ & $0.38^{*}$ & $0.58^{* *}$ & $0.83 * *$ & $0.60^{* *}$ \\
\hline 6 & (-)-Epigallocatechin & & & & & & 1 & n.s. & n.s. & n.s. & n.s. & n.s. & n.s. & n.s. & n.s. & n.s. & $-0.87^{* *}$ & n.s. & n.s. & $0.66^{* *}$ & $0.90^{* *}$ & $0.63^{* *}$ \\
\hline 7 & Resveratrol & & & & & & & 1 & n.s. & n.s. & n.s. & n.s. & $0.98^{* *}$ & $0.70^{* *}$ & $0.99^{* *}$ & $0.37^{*}$ & n.s. & n.s. & n.s. & n.s. & n.s. & n.s. \\
\hline 8 & Chlorogenic acid & & & & & & & & 1 & $0.90^{* *}$ & n.s. & n.s. & n.s. & n.s. & n.s. & n.s. & n.s. & n.s. & n.s. & $-0.48 * *$ & $-0.40 *$ & n.s. \\
\hline 9 & Coumaric acid & & & & & & & & & 1 & n.s. & n.s. & n.s. & n.s. & n.s. & n.s. & n.s. & n.s. & n.s. & n.s. & n.s. & n.s. \\
\hline 10 & Caffeic acid & & & & & & & & & & 1 & n.s. & n.s. & n.s. & n.s. & n.s. & n.s. & n.s. & n.s. & n.s. & n.s. & n.s. \\
\hline 11 & Rutin & & & & & & & & & & & 1 & & $0.82 * *$ & n.s. & $0.93^{* *}$ & n.s. & n.s. & n.s. & n.s. & n.s. & n.s. \\
\hline 12 & Delfinidin-3-O-glucoside & & & & & & & & & & & & 1 & $0.70^{* *}$ & $0.99^{* *}$ & 0.36 & n.s. & n.s. & n.s. & n.s. & n.s. & n.s. \\
\hline 13 & Cyanidin-3-O-glucoside & & & & & & & & & & & & & 1 & $0.71 * *$ & $0.89^{* *}$ & n.s. & n.s. & n.s. & n.s. & n.s. & n.s. \\
\hline 14 & Petunidin-3-O-glucoside & & & & & & & & & & & & & & 1 & 0.38 & n.s. & n.s. & n.s. & n.s. & n.s. & n.s. \\
\hline 15 & Malvidin-3-O-glucoside & & & & & & & & & & & & & & & 1 & n.s. & n.s. & n.s. & n.s. & n.s. & n.s. \\
\hline 16 & Tartaric acid & & & & & & & & & & & & & & & & 1 & $0.87^{* *}$ & n.s. & $-0.84 * *$ & $-0.96^{* *}$ & $-0.79 * *$ \\
\hline 17 & Malic acid & & & & & & & & & & & & & & & & & 1 & n.s. & $-0.76^{* *}$ & $-0.79^{* *}$ & $-0.70 * *$ \\
\hline 18 & Citric acid & & & & & & & & & & & & & & & & & & 1 & n.s. & n.s. & n.s. \\
\hline 19 & DPPH & & & & & & & & & & & & & & & & & & & 1 & $0.80^{* *}$ & $0.89^{* *}$ \\
\hline 20 & Cuprac & & & & & & & & & & & & & & & & & & & & 1 & $0.78^{* *}$ \\
\hline
\end{tabular}

1 Lipid peroxidation

The symbols mean: * correlation is significant at $\mathrm{p}<0.05,{ }^{* *}$ correlation is significant at $\mathrm{p}<0.01$, n.s. correlation is not significant ( $\mathrm{p}>0.05$ ). The numbers 1 to 21 correspond to the compounds 
associated with positive effects in human health (Xia et al., 2010; Mitić et al., 2012). Minors correlations found in this study suggest that scavenging of reactive species does not only depend on phenolics. Other compounds such as vitamins, minerals, carotenes, and their synergisms may contribute to the antioxidant activity as observed by Bunea et al. (2012). Based in our results, catechins are the major determinants for the antioxidant activities, which is in agreement with the results of Dani et al. (2007) and Radovanović et al. (2010), who, in previous studies with white and red grapes found that catechins were the most determinant the polyphenols for the antioxidant activities. They suggest that they can be easily used as biomarkers for the authentication of red grapes cultivars. We found similar antioxidant values and moderate levels of catechins in the white grapes of 'Dona Maria' cultivar, suggesting that catechins can be present in white grape cultivars, even if their level is low or moderate.

\section{CONCLUSIONS}

The results from this study shown that four table grapes grown in Douro region and its respective fractions of seeds and skins have high content of phytochemicals and high antioxidant activities, allowing to conclude that Douro region has suitable environmental conditions to produce the studied table grapes. Although the red grape cultivars presented the highest antioxidant activities linked with the high content of anthocyanins and catechins, the white cultivar 'Dona Maria' might be a very promising cultivar due to its diversity of polyphenols and high antioxidant activity; therefore, its production should be incremented.

\section{ACKNOWLEDGMENTS}

The authors acknowledge the financial support of European Investment Funds by FEDER/COMPETE/POCI-Operacional

Competitiveness and Internacionalization Programme, under Project POCI-01-0145-FEDER006958 and National Funds by FCT - Portuguese Foundation for Science and Technology, under the project UID/AGR/04033/2013.

The authors acknowledge the financial support of European Investment Funds by FEDER/NORTE2020 under the project INNOVINE\&WINE, NORTE-010145-FEDER-000038.

\section{REFERENCES}

Aires A., Carvalho R., Matos M., Cranide V., Silva A.P., Gonçalves B., 2017. Variation of chemical constituents, antioxidant activity and endogenous plant hormones throughout different ripening stages of highbush blueberry (Vaccinium corymbosum L.) cultivars produced in Centre of Portugal. J. Food Biochem., 41, e12414.

Apak R., Güçlü K., Özyürek M., Karademir S.E., 2004. Novel total antioxidant capacity index for dietary polyphenols and vitamins $\mathrm{C}$ and $\mathrm{E}$, using their cupric ion reducing capability in the presence of neocuproine: CUPRAC method. J. Agric. Food Chem., 52, 79707981.

Aubert C., Chalot G., 2018. Chemical composition, bioactive compounds, and volatiles of six table grape varieties (Vitis vinifera L.). Food Chem., 240, 524-533.

Aurand J.-M., 2017. Point de conjoncture vitivinicole mondiale 2017. In: Conference de Presses. 24 Octobre 2017. International Organisation of Vine and Wine, Paris. http://www.oiv.int/public/medias/5679/conf-rence-de-presse-oivoctobre-2017.pdf (accessed 1 February 2018).

Bunea C.-I., Pop N., Babeș A.C., Matea C., Dulf F.V., Bunea A., 2012. Carotenoids, total polyphenols and antioxidant activity of grapes (Vitis vinifera) cultivated in organic and conventional systems. Chem. Cent. J., 6, 66.

Cantos E., Espín J.C., Tomás-Barberán F.A., 2002. Varietal differences among the polyphenol profiles of seven table grapes cultivars studied by LC-DAD-M-S-MS. J. agric. Food Chem., 50, 5691-5696.

Castillo-Muñoz N., Gómez-Alonso S., García-Romero E., Hermosín-Gutiérrez I., 2007. Flavonol profiles of Vitis vinifera red grapes and their single-cultivar wines. J. Agric. Food Chem., 55, 992-1002.

Dakera M., Abdullah N., Vikineswary S., Goh P.C., Kuppusamy U.R., 2008. Antioxidant from maize and maize fermented by Marasmiellus sp. as stabiliser of lipid-rich foods. Food Chem., 107, 1092-1098.

Dani C., Oliboni L.S., Vanderlinde R., Bonatto D., Salvador M., Henriques J.A.P., 2007. Phenolic content and antioxidant activities of white and purple juices manufactured with organically-orconventionally-produced grapes. Food Chem. Toxicol., 45, 25742580 .

Daniel P.F., De Feudis D.F, Lott I. T., McCluer R.H., 1981. Quantitative microanalysis of oligosaccharides by high performance liquid chromatography. Carbohydr. Res., 97, 161-180.

Ferrandino A, Carra A, Rolle L, Schneider A, Schubert A., 2012. Profiling of hydroxycinnamoyl tartrates and acylated anthocyanins in the skin of 34 Vitis vinifera genotypes. J. Agric. Food Chem., 60, 4931-4945.

Flamini R., Mattivi F., Rosso M.D., Arapitsas P., Bavaresco L., 2013. Advanced knowledge of three important classes of grape phenolics: anthocyanins, stilbenes and flavonols. Int. J. Mol. Sci. 14, 19651-19669.

Ganeshpurkar A., Saluja A.K., 2017. The pharmacological potential of rutin. Saudi Pharm. J., 25, 149-164.

Georgiev V., Ananga A., Tsolova V., 2014. Recent advances and uses of grape flavonoids as nutraceuticals. Nutr., 6, 391-415.

He F., Liang N.-N., Duan C.-Q., Wang J., Reeves M.J., 2017. Accumulation of anthocyanins in the skin and pulp of five different teinturier grapes. Acta Hortic., 1157, 73-82. 
He J.-J., Liu Y.-X., Pan Q.-H., Cui X.-Y., Duan C.-Q., 2010. Different Anthocyanin Profiles of the Skin and the Pulp of Yan73 (Muscat Hamburg $\times$ Alicante Bouschet) Grape Berries. Molecules, 15, 1141-1153.

Higdon J.V, Frei B., 2003. Tea catechins and polyphenols: health effects, metabolism, and antioxidant functions. Crit. Rev. Food Sci. Nutr., 43, 89-143.

Hussain T., Tan B., Yin Y., Blachier F., Tossou M. C. B., Rahu N., 2016. Oxidative stress and inflammation: what polyphenols can do for us? Oxid. Med. Cell. Longev., 2016, ID 7432797, 1-9.

Isci B., Gokbayrak Z., Keskin N., 2015. Effects of cultural practices on total phenolics and vitamin $\mathrm{C}$ content of organic table grapes. S. Afr. J. Enol. Vitic., 36, 191-194.

IVV, 2017a. Evolução da Produção Nacional de Vinho por Região Vitivinícola, Série 2000/2001 a 2017/2018. Instituto da Vinha e do Vinho. http://www.ivv.gov.pt/np4/36/ (accessed 1 February 2018).

IVV, 2017b. Castas mais utilizadas. Instituto da Vinha e do Vinho. http://www.ivv.gov.pt/np4/35/ (accessed 1 February 2018).

Jogaiah S., Oulkar D.P., Vijapure A.N., Maske S.R., Sharma A.K., Somkuwar R.G., 2013. Influences of canopy management practices on fruit composition of wine grape cultivars grown in semi-arid tropical region of India. Afr. J. Agric. Res., 8, 3462-3472.

Kok D., 2014. A review on grape growing in tropical regions. Turk. J. Agric. Nat. Sci., 1, 1236-1241

Kok D., 2016. Variation in total phenolic compounds, anthocyanin and monoterpene content of 'Muscat Hamburg' table grape cultivar $(V$. vinifera $\mathrm{L}$.) as affected by cluster thinning and early and late period basal leaf removal treatments. Erwerbs-Obstbau., 58, 241246.

Kumar S., Pandey A.K., 2013. Chemistry and biological activities of flavonoids: an overview. Sci. World J., 2013, 162750.

Liang N., Kitts D.D., 2016. Role of chlorogenic acids in controlling oxidative and inflammatory stress conditions. Nutr., 8, 16

Marreiros C., 2013. O potencial de produção e comercialização de uvas "D. Maria" em Portugal. MSc Thesis, Universidade de Évora.

Mendes-Pinto M.M., Ferreira A.C.S., Oliveira M.B.P.P., Pinho P.G., 2004. Evaluation of some carotenoids in grapes by reversedand normal-phase liquid chromatography: a qualitative analysis. $J$. Agric. Food Chem., 52, 3182-3188.

Mitić M.N., Souquet J.-M., Obradović M.V., Mitić S., 2012. Phytochemical profiles and antioxidant activities of Serbian table and wine grapes. Food Sci. Biotechnol., 21, 1619-1626.

OIV, 2017. State of the vitiviniculture world market. http://www.oiv.int/public/medias/5287/oiv-noteconjmars2017en.pdf (accessed 1 February 2018).

Oliveira D.A., Salvador A.A., Smânia A., Smânia E.F.A., Maraschin M., Ferreira S.R.S., 2013. Antimicrobial activity and composition profile of grape (Vitis vinifera) pomace extracts obtained by supercritical fluids. J. Biotechnol., 164, 423-432.

Philips M.M., Case R.J., Rimmer C.A., Sander L.C., Sharpless K.E., Wise S.A., Yen J.H., 2010. Determination of organic acids in Vaccinium berry standard reference materials. Anal. Bioanal. Chem., 398, 425-434
Radovanović B., Radovanović A., Souquet J., 2010. Phenolic profile and free radical-scavenging activity of cabernet Sauvignon wines of different geographical origins from Balkan region. J. Sci. Food Agric., 90, 2455-2461.

Ras R.T., Zock P.L., Zebregs Y.E., Johnston N.R., Webb D.J., Draijer R., 2013. Effect of polyphenol-rich grape seed extract on ambulatory blood pressure in subjects with pre- and stage I hypertension. Br. J. Nutr., 110, 2234-2241

Rasines-Perea Z., Teissedre P.-L., 2017. Grape polyphenols effects in human cardiovascular diseases and diabetes. Molecules, 22, 68

Remaily G.W., 1987. Diversity of North American species of Vitis. Plant Gen. Resour. Nwslt., 71, 25-30.

Rockenbach I.I., Gonzaga L.V., Rizelio V.M., Gonçalves A.E.S.S. Genovese M.I., Fett R., 2011. Phenolic compounds and antioxidant activity of seed and skin extracts of red grape (Vitis vinifera and Vitis labrusca) pomace from Brazilian winemaking. Food Res Int., 44, 897-901.

Rolle L., Giacosa S., Gerbi V., Bertolino M., Novello V., 2013. Varietal comparison of the chemical, physical, and mechanical properties of five colored table grapes. Int. J. Food Prop., 16, 598612

Nile S.H., Kim D.H., Keum Y.-S., 2015. Determination of anthocyanins content and antioxidant capacity of different grape varieties. Ciência Téc. Vitiv., 30, 60-68.

Siddhraju P., Becker K., 2003. Antioxidant properties of various solvents extracts of total phenolic constituents from three different agroclimatic origins of drumstick tree (Moringa oleifera Lam) leaves. J. Agric. Food Chem., 51, 2144-2155.

Sosa V., Moliné T., Somoza R., Paciucci R., Kondoh H.E., LLeonart M.E., 2013. Oxidative stress and cancer: an overview. Ageing Res. Rev., 12, 376-390.

Topalovic A., Godjevac D., Perovic N., Trifunovic S., 2012. Comparative study of the phenolic composition of seeds from grapes cv Cardinal and Alphonse lavalleé during last month of ripening. Ital. J. Food Sci., 24, 159-166.

Topalovic A. Mikulic-Petkovsek M., 2010. Changes in sugars, organic acids and phenolics of grape berries of cultivar Cardinal during ripening. J. Food Agric Environ., 8, 223-227.

Vaisman N., Niv E., 2015. Daily consumption of red grape cell powder in a dietary dose improves cardiovascular parameters: A double blind, placebo-controlled, randomized study. Int. J. Food Sci. Nutr., 66, 342-349.

Xia E.-Q., Deng G.-F., Guo Y.J., Li H.B., 2010. Biological activities of polyphenols from grapes. Int. J. Mol. Sci., 11, 622 646

Yang J., Martinson T.E., Liu R.H., 2009. Phytochemical profiles and antioxidant activities of wine grapes. Food Chem., 116, 332 339.

Yilmaz Y., Göksel Z., Erdoğan S.S., Öztürk A., Atak A., Özer C., 2015. Antioxidant activity and phenolic content of seed, skin and pulp parts of 22 grapes (Vitis vinifera $\mathrm{L}$.) cultivars (4 common and 18 registered or candidate for resgistration). J. Food Process., 39 , 1682-1691 